「性能を診断し，達成する制御」総合特集号

\title{
データ指向型スマート適応制御系の一設計*
}

\author{
木下＼cjkstart拓矢 ${ }^{\dagger} \cdot$ 脇谷＼cjkstart伸 †・中本 昌由 + 山本＼cjkstart透
}

\section{Design of a Data-Oriented Smart Adaptive Controller*}

\author{
Takuya Kinoshita ${ }^{\dagger}$, Shin WAKITAni $^{\dagger}$, Masayoshi NAKAmoto ${ }^{\ddagger}$ and Toru YAmAmoto Y $^{\ddagger}$
}

\begin{abstract}
Data-oriented controllers are emerging as an alternative to model-based controllers designs, due to the fact that data-oriented controllers enhance the closed-loop behavior of the system by using very simple structures. This paper studies how to evaluate the control performance of a closed-loop data as well as how to adjust the control parameters to improve the control performance.

PID control method based on Generalized Minimum Variance Controller (GMVC) is considered. When the control performance is deteriorated due to changes in control parameters, the closedloop data are utilized to re-adjust the direct system parameters. Simulation results are provided to demonstrate the effectiveness of the proposed control scheme.
\end{abstract}

\section{1. 緒言}

近年, プロセス産業界においては，国際競争の激化や エネルギー問題などから, 生産性や品質の向上, 省エネ ルギー化・省力化などが進められており，制御システム が果たす役割は, これまで以上に重要視されてきている. とくに, システムの操業条件の変更や環境の変化などに よってシステムの特性は大きく変化することがあり，所 望の制御性能を維持するためには，七ルフチューニング 制御 [1-6] や適応制御 [7-11] のように，オンラインで制 御パラメー夕を変更するような仕組みが必要であると考 えられる。しかしながら, 制御パラメータの逐次調整は, 計算コストや信頼性の観点から，必ずしも実用的ではな く, 制御性能が劣化したときのみ, 制御パラメータが変 更されるという，いわゆる Tuning on Demandの考え

* 原稿受付 2013 年 6 月 4 日

$\dagger$ 広島大学大学院 工学研究科 Graduate School of Engineering, Hiroshima University; 1-4-1 Kagamiyama, Higashihiroshima city, Hiroshima 739-8527, JAPAN

‡広島大学工学研究院 電気電子システム数理部門 Faculty of Engineering Division of Electrical, Systems and Mathematical Engineering, Hiroshima University; 1-41 Kagamiyama, Higashihiroshima city, Hiroshima 7398527, JAPAN

Key Words: PID control, generalized minimum variance control, control performance assessment, closed-loop data, data-oriented control.
方の方が，より実用的であると考えられる。すなわち， 「制御性能評価」と「制御系設計」を統合したアプロー チが必要になってくる.

ところで,「制御性能評価」と「制御系設計」を統合し たパフォーマンス駆動型制御については，今までにいく つか報告されている [12-16]. しかしながら，いずれの 方法も，制御系の再設計（制御パラメータの再調整）の 際には，まず，入出力データからシステムモデルを構築 し，そのモデルに基づいて制御パラメータを算出する方 法に基づいている.

一方，閉ループデータからモデルを構築することなく， 制御パラメータを直接設計する方法について, VRFT 法 [17], FRIT 法 [18], さらには非反証制御法 [19] など, ここ数年, 盛んに研究が進められている。著者らも，一 般化最小分散制御 [2] との関連で, 閉ループデータから直 接 PID パラメータを算出する方法を提案している [20].

本論文では，閉ループデータから制御性能を評価し， 必要に応じて制御パラメータを調整する方法について 考察する，具体的には，著者らがこれまでに考察してい る一般化最小分散制御に基づく PID パラメータの調整 法を取り上げ, これに含まれる可調整パラメータの変更 によって, 制御性能を改善することを考える。しかしな がら，システムの特性が大きく変化するなど，制御パラ メータの再調整が必要な場合は, 閉ループデータを用い て制御パラメータを算出する。このように「1-パラメー 
タチューニング」と「制御パラメータの再調整」を組み 合わせることにより，パラメータ同定回数を必要最低限 に減らし，所望の制御性能を維持することを目指す。こ のとき, システムモデルを構築することなく, 閉ループ データから直接, 制御パラメータを再調整することを考 える。このように，(1) 閉ループデータのみを用いて「制 御性能評価」と「制御系設計」を行う, (2) 必要に応じて 効率的に制御パラメータを調整する，という意味で，本 論文で提案する制御法を「データ指向型スマート適応制 御法」とよぶ.

なお，制御性能が劣化する場合として，1) 制御対象そ のものの不備・故障に伴う場合，2) コントローラの構造 (次数) のミスマッチによる場合， 3 ) 外乱の影響による 場合，4) 制御パラメータの不具合による場合が考えられ るが，本論文では，4)を扱う。

本論文では，まず，提案する「デー夕指向型スマート 適応制御系」の概要を述へ，具体的な制御法について説 明する。このとき,「制御性能評価」を概説したうえで, 「制御系設計」との関連について考察する。最後に，提 案手法の有効性を数值例によって検証する.

\section{2. データ指向型スマート適応制御系の設計}

\section{1 制御系の概要}

本論文で提案するデー夕指向型スマート適応制御系 の概要図を Fig. 1 に示し，本制御系を簡単に説明する. まず，制御性能（定常状態における制御誤差の分散と制 御入力の変化量の分散) をあらかじめ設定しておく，そ のうえで,「制御性能評価機構」(Control Performance Monitoring)において, 所望の制御性能と現在の制御性 能を比較し, 制御性能が劣化した場合にPID コントロー ラを調整する。このとき, 基本的には,「1-パラメー夕調整 器」(1-Parameter Tuner)のみでPID コントローラを調 整することとする.「制御パラメー夕算出器」(Parameter Calculator) については，あくまで制御対象の特性変動 が大き過ぎる場合のみに機能（コントローラ再設計）す る, 補助的な役割を担う.

ここで, 制御パラメータの算出には, 一般化最小 分散制御 (Generalized Minimum Variance Control: GMVC)[2] に基づく PID パラメータの直接的算出法 である GMV-PID 制御系の設計法 [20] を用いている。

\subsection{GMV-PID 制御系の設計}

\subsection{1 直接型一般化最小分散制御}

制御対象が次式で記述できるものとする.

$$
\left.\begin{array}{c}
A\left(z^{-1}\right) y(t)=z^{-1} B\left(z^{-1}\right) u(t)+\xi(t) / \Delta \\
A\left(z^{-1}\right)=1+a_{1} z^{-1}+a_{2} z^{-2} \\
B\left(z^{-1}\right)=b_{0}+b_{1} z^{-1}+\ldots+b_{m} z^{-m}
\end{array}\right\}
$$

(1) 式において, $u(t)$ は制御入力, $y(t)$ はシステム出 力, ならびに $\xi(\mathrm{t})$ は平均 0 , 分散 $\sigma^{2}$ のガウス性白色

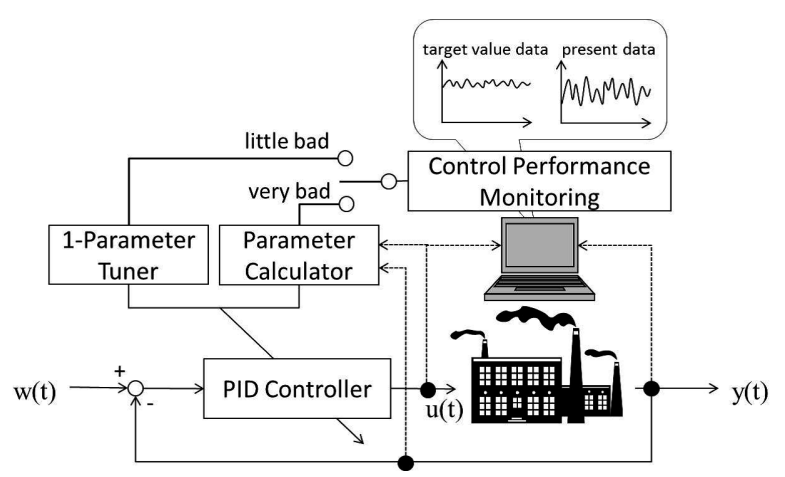

Fig. 1 Schematic figure of the data-oriented smart adaptive controller

雑音を示している。また， $z^{-1}$ は時間遅れ演算子で, $z^{-1} y(t)=y(t-1)$ である. $\Delta$ は差分演算子を表しており， $\Delta:=1-z^{-1}$ で定義される.ささらに, $m$ は $B\left(z^{-1}\right)$ の次 数を表す。なお，むだ時間はゼロとしており，それによ り, 後述する trade-off 曲線を, システムモデルなしで取 得している.

(1) 式のシステムに対して, 以下の評価規範の最小化 に基づく一般化最小分散制御則を導出する。

$$
J=E\left[\phi^{2}(t+1)\right]
$$

$\phi(t+1)$ は一般化出力であり, 次式で与えられる.

$$
\phi(t+1):=P\left(z^{-1}\right) y(t+1)+\lambda \Delta u(t)-P(1) w(t)
$$

ここで $w(t)$ はステップ状の目標值を表している。また， $\lambda$ は入力の変化量に対する重み係数であり, 後述する trade-off 曲線の制御誤差の分散に基づいて決定される. つぎに（5) 式で与えられる Diophantine 方程式を導入 する。

$$
\begin{aligned}
& P\left(z^{-1}\right)=\Delta A\left(z^{-1}\right)+z^{-1} F\left(z^{-1}\right) \\
& F\left(z^{-1}\right)=f_{0}+f_{1} z^{-1}+f_{2} z^{-2}
\end{aligned}
$$

さらに, $P\left(z^{-1}\right)$ は設計多項式であり参考文献 [5]に基づ いて設計される。

$$
\left.\begin{array}{rl} 
& P\left(z^{-1}\right)=1+p_{1} z^{-1}+p_{2} z^{-2} \\
p_{1}= & -2 \exp \left(-\frac{\rho}{2 \mu}\right) \cos \left(\frac{\sqrt{4 \mu-1}}{2 \mu} \rho\right) \\
p_{2}= & \exp \left(-\frac{\rho}{\mu}\right) \\
\rho:= & T_{s} / \sigma \\
\mu:= & 0.25(1-\delta)+0.51 \delta
\end{array}\right\}
$$

(8) 式において， $\sigma ， \delta$ はそれぞれ制御系の立ち上がり 特性, 減衰特性に関係するパラメータであり, 設計者が 任意に設定する。設計の見通しを良くするために，事 前情報から $\sigma$ は，おおむね時定数とむだ時間の総和の $1 / 3 \sim 1 / 2$ 程度に設定する。 また， $\delta$ は， $0 \leq \delta \leq 2.0$ の 間で設定されることが望ましいとされ，とくに $\delta=0$ は 
Binominal モデルの応答を, $\delta=1.0$ は Butterworth モ デルの応答を示す.

(1)，(4) および (5) 式から, 次式で表される一般化出 力の時刻 $t$ における一段先出力值を得る.

$$
\begin{aligned}
\phi(t+1 \mid t)= & F\left(z^{-1}\right) y(t)+\left\{B\left(z^{-1}\right)+\lambda\right\} \Delta u(t) \\
& -P(1) w(t)+\xi(t+1)
\end{aligned}
$$

ここで，時刻 $t$ における一段先最適予測值を以下のよう に定義する.

$$
\begin{aligned}
\hat{\phi}(t+1 \mid t):= & F\left(z^{-1}\right) y(t)+\left\{B\left(z^{-1}\right)+\lambda\right\} \Delta u(t) \\
& -P(1) w(t)
\end{aligned}
$$

また (9), (10) 式より次式を得る.

$$
\phi(t+1 \mid t)=\hat{\phi}(t+1 \mid t)+\xi(t+1)
$$

(3), (11) 式より, $\hat{\phi}(t+1 \mid t)=0$ とすることで, 評価規 範 $J$ を最小化するような一般化最小分散制御則 (12) 式 が導出される.

$$
\Delta u(t)=\frac{P(1)}{B\left(z^{-1}\right)+\lambda} w(t)-\frac{F\left(z^{-1}\right)}{B\left(z^{-1}\right)+\lambda} y(t)
$$

本論文では GMVC の直接法に基づき，一回で得られた 閉ループデータから，システム同定を介すことなく直接 的に制御パラメータの算出を行う。具体的には一般化出 力と最適予測值の予測誤差を以下のように定義する.

$$
\varepsilon(t+1):=\phi(t+1)-\hat{\phi}(t+1 \mid t)
$$

この残差の平方和が最小となるように，得られた閉ルー プデータに対して最小 2 乗法を適用することで, $F\left(z^{-1}\right)$ および $B\left(z^{-1}\right)$ のパラメータを直接算出する $[3,4]$. 得ら れた制御パラメータ $F\left(z^{-1}\right), B\left(z^{-1}\right) を ，(12)$ 式の一般 化最小分散制御則に適用することにより，閉ループデー 夕に基づく一般化最小分散制御系の直接的な設計が可能 となる $[20]$.

\subsection{2 比例 - 微分先行型 PID 制御則への置き換え}

つぎに，先の直接型 GMVCによって算出された制御 パラメータを PID ゲインに置き換える $[5,12,20]$. まず, 制御則として次式の比例・微分先行型 PID 制御則を考 える。

$$
\begin{aligned}
\Delta u(t) & =\frac{k_{c} T_{s}}{T_{I}} e(t)-k_{c}\left(\Delta+\frac{T_{D}}{T_{s}} \Delta^{2}\right) y(t) \\
e(t): & =w(t)-y(t)
\end{aligned}
$$

ここで, $k_{c}, T_{I}, T_{D}$ はそれぞれ，比例ゲイン，積分時 間，微分時間を表す。また， $T_{s}$ はサンプリング時間で ある。つぎに, (12) 式において多項式 $B\left(z^{-1}\right)$ を定常項 $B(1)$ に置き換えることで次式を得る.

$$
\Delta u(t)=\frac{P(1)}{B(1)+\lambda} w(t)-\frac{F\left(z^{-1}\right)}{B(1)+\lambda} y(t)
$$

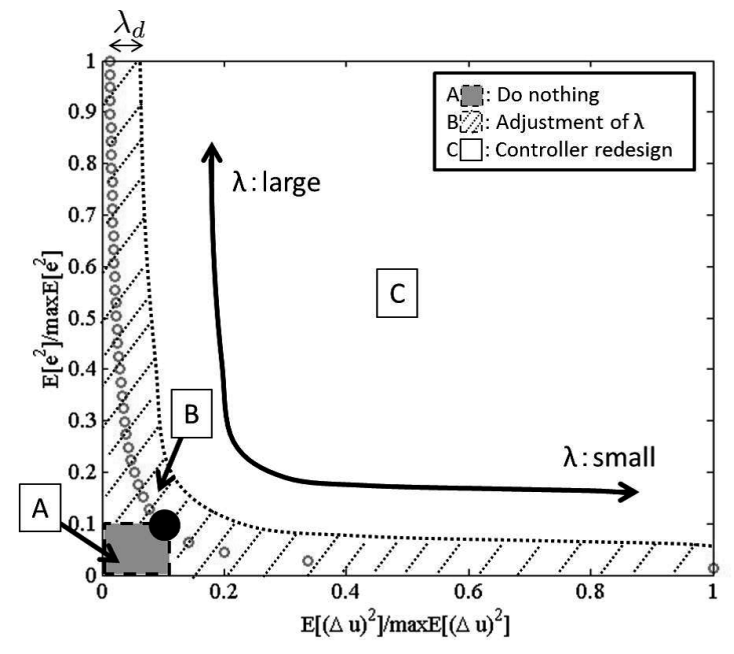

Fig. 2 Trade-off curve indicated by changing $\lambda$

(14) 式と (16) 式の係数を比較すれば,

$$
\left.\begin{array}{l}
k_{c}=-\frac{f_{1}+2 f_{2}}{B(1)+\lambda} \\
T_{I}=-\frac{f_{1}+2 f_{2}}{f_{0}+f_{1}+f_{2}} T_{s} \\
T_{D}=-\frac{f_{2}}{f_{1}+2 f_{2}} T_{s}
\end{array}\right\}
$$

となり，近似的に GMVCの制御パラメータを PID ゲイ ンに置き換えることができる。

\section{3 制御性能評価に基づく $\lambda$ の調整}

本論文では，GMV-PID における $\lambda$ ，制御誤差と制 御入力の変化量の分散 (以降は, 簡単のために制御入力 の分散という）の双方に基づいて調整することを考える. GMV-PID において， $\lambda$ をある変化幅 $\Delta \lambda$ ずつ変化させ たとき, Fig. 2 の B 領域“○’印でプロットされるtrade-off 曲線が得られる。縦軸は定常状態での制御誤差信号の分 散 $E\left[e^{2}(t)\right]$, 横軸は制御入力の分散 $E\left[\{\Delta u(t)\}^{2}\right]$ を示し ており，それぞれの最大值で除算することで正規化して いる. A, B, C 領域の詳細については後述する.

Fig. 2 から明らかなように，入を $\Delta \lambda$ ずつ変化させるこ とで, 制御誤差の分散 $E\left[e^{2}(t)\right]$ と入力の分散 $E\left[\{\Delta u(t)\}^{2}\right]$ が変化する。このとき, 所望の制御性能を満たす $\lambda$ の決 定が重要であるが，ここでは，あらかじめユーザが所望 の制御性能である制御誤差の分散 $\sigma_{e}^{2}$ を指定し，それを 満足する中で, 制御入力の分散が最も小さくなるように, $\lambda$ を決定することを考える. Fig. 2の例では, 所望の制 御性能は図中の ‘’で示す点とする。つまりこれより内 側の A 領域に収まるように制御すれば所望の制御性能, あるいはそれ以上の制御性能が得られていることになる.

しかしながら, 制御対象の特性が時間的に変化する場 合は制御性能が $\mathrm{A}$ 領域に収まらず， B 領域や C 領域に移 り所望の制御性能が得られない場合がある。よって本論 
文では, B 領域においては trade-off 曲線に沿った制御性 能であるとして，入のみの1-パラメータチューニングに より所望の制御性能を維持する方法を提案する。また, trade-off曲線から離れた C 領域においては， $\lambda$ による調 整は困難であると考えられるため, 閉ループデータを用 いて制御パラメータを再調整する。なお, trade-off 曲線 から B 領域と $\mathrm{C}$ 領域の境界線までの幅 $\lambda_{d}$ はユーザが任 意に設定する.

制御誤差 $e(t)$ と制御入力 $\Delta u(t)$ の分散は, 参考文 献 [12] より， $H_{2}$ ノルム $\|\cdot\|_{2}$ を用いて次式により計算 することができる.

$$
\begin{aligned}
E\left[e^{2}(t)\right] & =\left\|-\frac{1}{T\left(z^{-1}\right)}\right\|_{2}^{2} \sigma_{\epsilon}^{2} \\
E\left[\{\Delta u(t)\}^{2}\right] & =\left\|-\frac{C\left(z^{-1}\right)}{T\left(z^{-1}\right)}\right\|_{2}^{2} \sigma_{\epsilon}^{2}
\end{aligned}
$$

ここで, $T\left(z^{-1}\right), C\left(z^{-1}\right)$ は次式により定義される.

$$
\begin{aligned}
& T\left(z^{-1}\right):=\Delta A\left(z^{-1}\right)+z^{-1} B\left(z^{-1}\right) C\left(z^{-1}\right) \\
& C\left(z^{-1}\right):=\frac{F\left(z^{-1}\right)}{B(1)+\lambda}
\end{aligned}
$$

いま, $(20)$ 式においては, $T\left(z^{-1}\right)$ の算出にシステムパラ メータ $A\left(z^{-1}\right)$ を必要とするが, (13) 式の最小化によっ て算出された $F\left(z^{-1}\right)$ および $B\left(z^{-1}\right)$ と $(5)$ 式の関係を 用いて，(20)式は次式のように書き換えられる.

$$
\begin{aligned}
T\left(z^{-1}\right)= & P\left(z^{-1}\right) \\
& +z^{-1}\left\{B\left(z^{-1}\right) C\left(z^{-1}\right)-F\left(z^{-1}\right)\right\}
\end{aligned}
$$

また, $\sigma_{\epsilon}$ は推定モデル出力と実際のシステム出力の誤差 の標準偏差を示しているが, ここでは $\sigma_{\epsilon}$ の值は未知で あるので, (13) 式で算出する $\varepsilon$ 標準偏差 $\sigma_{\varepsilon}$ に代えて 計算する。

なお,「1-パラメー夕調整器」と「制御パラメー夕算出 器」の切替えが安定性に影響を及ぼす場合が考えられる が，切替えの際は，入を大きくとることによって，比例 ゲインの大きな変動を回避させることができる.

\section{4 スマート適応制御系設計アルゴリズム}

これまでに考察してきた個々の手続きを統合し，ス マート適応制御系を構築する. Fig. 2 を用いてアルゴリ ズムを以下に示す。ただし， $N$ はデー夕数であり，制御 誤差の分散 $E\left[e^{2}(t)\right]$ と制御入力の分散 $E\left[\{\Delta u(t)\}^{2}\right]$ に関 するものは簡単化のためにすべて正規化しているものと する。 また，それぞれの分散はエルゴード性が成り立つ とし，時間平均として計算する.

$1^{o}$ 安定な制御器を用いて閉ループデータを取得する.

$2^{o}$ GMVC に基づき, データから $F\left(z^{-1}\right), B\left(z^{-1}\right)$ を算出する。ささに, $(21),(22)$ 式から $T\left(z^{-1}\right)$, $C\left(z^{-1}\right)$ を算出する.

$3^{o} \lambda$ を変化させて PID コントローラ (GMV-PID) を
設計する. このとき $2^{o}$ で算出した $T\left(z^{-1}\right), C\left(z^{-1}\right)$ を利用し，それぞれの入に対応した (18), (19) 式 を計算することで, 初回のみ Fig. 2 の trade-off 曲 線を描く(それ以降は描かない)。

$4^{o}$ あらかじめ設定した制御誤差の分散 $\sigma_{e}^{2}$ を満足する 中で, 制御入力の分散が最も小さくなるポイント $\left(E\left[\{\Delta u(t)\}^{2}\right]_{\min }, E\left[e^{2}(t)\right]_{\min }:\right.$ Fig. 2 の •’印) を算出し，これに対応する $\lambda$ ，ならびにPID ゲイ ンを制御系に採用する。 また，Fig. 2 の‘・印と原 点を通る直線の傾き $J_{r}$ を以下の式で算出しておく.

$$
J_{r}=\frac{E\left[e^{2}(t)\right]_{\min }}{E\left[\{\Delta u(t)\}^{2}\right]_{\min }}
$$

$5^{o} N$ ステップ間， $4^{o}$ で採用した PID ゲインにて制御 する.

$6^{o}$ 時刻 $t$ から $N$ ステップ前までのデータを用いて, 現在の制御誤差の分散 $E\left[e^{2}(t)\right]$ と制御入力の分散 $E\left[\{\Delta u(t)\}^{2}\right]$ を計算し, その現在の分散が Fig. 2 の $\mathrm{A}, \mathrm{B}, \mathrm{C}$ のどの領域に位置しているのかを調べ る。また，現在の分散の傾きとして以下の式を算 出しておく.

$$
J(t)=\frac{E\left[e^{2}(t)\right]}{E\left[\{\Delta u(t)\}^{2}\right]}
$$

$7^{\circ} 6^{\circ}$ の現在の分散 $E\left[e^{2}(t)\right], E\left[(\Delta u(t))^{2}\right]$ が $\mathrm{A}$ 領域に 位置するなら $9^{\circ}$ へ進み, $\mathrm{B}$ 領域ならば $8^{\circ}$ へ進み, $\mathrm{C}$ ならば $2^{\circ}$ へ戻る $\left(2^{o}\right.$ へ戻るたびに $N$ 個のデー 夕を使用).

$8^{\circ} \lambda$ を再選定し, それに対応する PID ゲインを制御 系に採用する。このとき, Fig. 2: ‘’印に 60 の現 在の分散 $E\left[e^{2}(t)\right], E\left[\{\Delta u(t)\}^{2}\right]$ が近づくように $4^{o}$ で定めた $\lambda$ を $\Delta \lambda$ 分増減させる。具体的には以 下の式を満たすときに $\lambda=\lambda+\Delta \lambda$ とし, 満たさな いときは $\lambda=\lambda-\Delta \lambda$ とする。

$$
J(t)<J_{r}
$$

$9^{o} \quad t=t+1$

$10^{\circ} 6^{o}$ へ戻る.

本制御系の安定性は, 可調整パラメータ $\lambda$ に大きく左 右される。前述したように，安定性を重視する場合は， ステップ $4^{o}$ において $\lambda$ を大きく設定することで対応する，

\section{3. 数值例}

本手法の有効性を, 数值例により検証を行う。なお, $w(t)=10, m=3, N=500, \lambda_{d}=0.03, \Delta \lambda=0.02$ とした.

[例 1]

$\mathrm{PID}$ パラメータの初期チューニングの際に本手法を適 用することを想定する. 制御系対象として次式の「1 次 遅れ十むだ時間」系を考える。 


$$
G(s)=\frac{0.9}{1+100 s} e^{-15 s}
$$

(26) 式をサンプリング時間 $T_{s}=5.0[\mathrm{~s}]$ で離散化すれば以 下のようになる。

$$
\left(1-0.951 z^{-1}\right) y(t)=0.044 z^{-4} u(t)+\xi(t) / \Delta
$$

ただし，(27) 式にモデル化誤差として平均 0 , 分散 0.001 のガウス性白色雑音 $\xi(t)$ を付加したモデルを制御対象と する.

この制御対象に対して，提案手法を適用する。所望の 制御性能としての制御誤差の分散は $\sigma_{e}^{2}=0.2$ としたとき の制御結果を Fig. 3 に示す。ただし，最初の 1000 [step] においては，閉ループデータの取得のためにZiegler and Nicholsの調整則 [21] によって算出された，以下のPID ゲインを用いて制御を行う。

$$
k_{c}=8.90, T_{I}=30.0, T_{D}=7.50
$$

つぎに, 1000 ステップ間の入出力データを用いて,$t=$ 1000 [step] の時点で, 提案手法のアルゴリズムを適用し 制御を行う。なお，このときの設計多項式 $P\left(z^{-1}\right)$ は次 式のように設計した $\left(\sigma=50, \delta=0, T_{s}=5\right)$.

$$
P\left(z^{-1}\right)=1-1.64 z^{-1}+0.67 z^{-2}
$$

また，アルゴリズムの $3^{\circ}$ において， $\lambda$ は $0.0 \leq \lambda \leq 1.0$ の 間で変化させた。このとき，閉ループデータから得られ

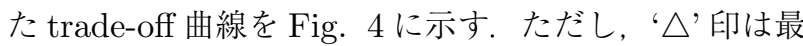
初の 1000 ステップにおける制御性能（制御誤差と制御 入力の分散）を示している。また，‘・は，本アルゴリズ ムによって特定した所望の制御性能を示している。この とき, $\lambda=0.03$, 所望の制御入力の分散は 0.13 が算出さ れた。

Fig. 3 と Fig. 4 より，提案手法を適用したことで，制 御誤差および制御入力の双方の分散が，効果的に抑えら

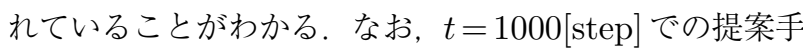
法適用により， $\sigma_{\varepsilon}=0.0311$ であり，算出された PID パ ラメータは,

$$
k_{c}=3.73, T_{I}=41.7, T_{D}=0.33
$$

であった。ささらに $1000[$ step] から 2000 [step] 間の制御 誤差の分散は，0.19であり，最初に指定した望ましい制 御誤差の分散 $\left(\sigma_{e}^{2}=0.2\right)$ に，おおむね近い值となって いる。同様に $1000[\mathrm{step}$ から 2000 [step] 間の制御入力の 分散は 0.14 であり所望の制御入力の分散（0.13）に近い 值となっている.

つぎに, 同様のシミュレーションを, $\sigma_{e}^{2}=0.8$ として 行った結果を Fig. 5 に示す。なお， $\sigma_{e}^{2}$ を除いた設計パ ラメータは，先と同じ值に設定した。このとき所望の制 御入力の分散は 0.042 が算出された.

あらかじめ設定する $\sigma_{e}^{2}$ を大きくすると, 制御誤差の分
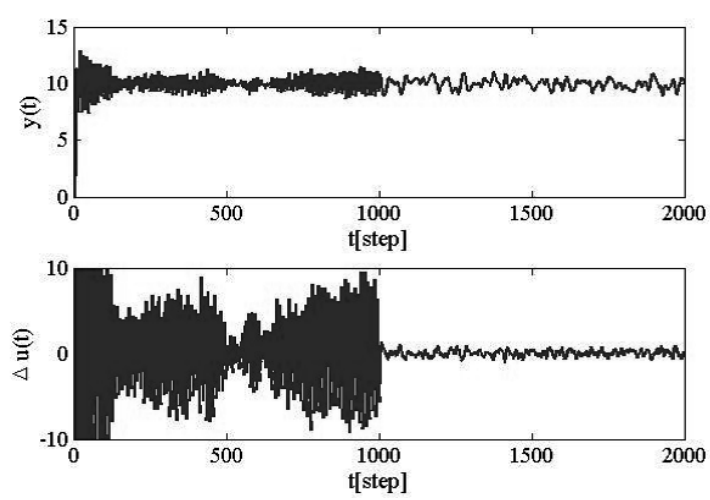

Fig. 3 Control result using the proposed control scheme in the case of $\sigma_{e}^{2}=0.2$

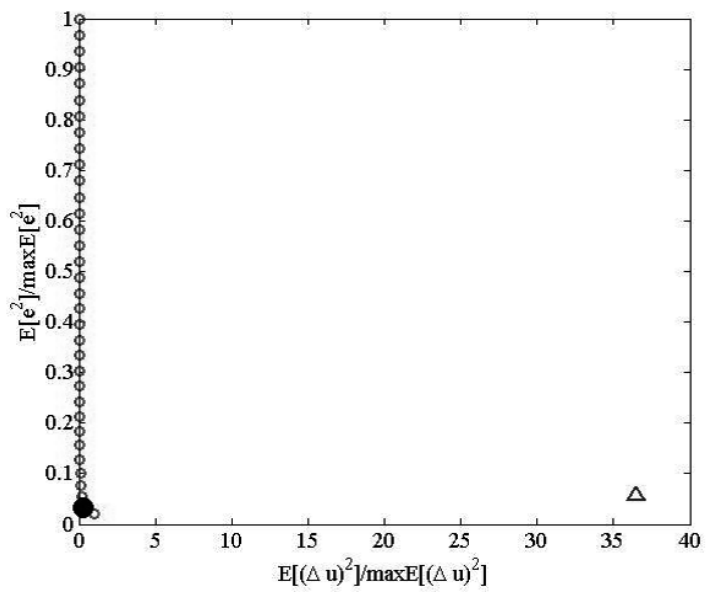

Fig. 4 Trade-off curve indicated by changing $\lambda$
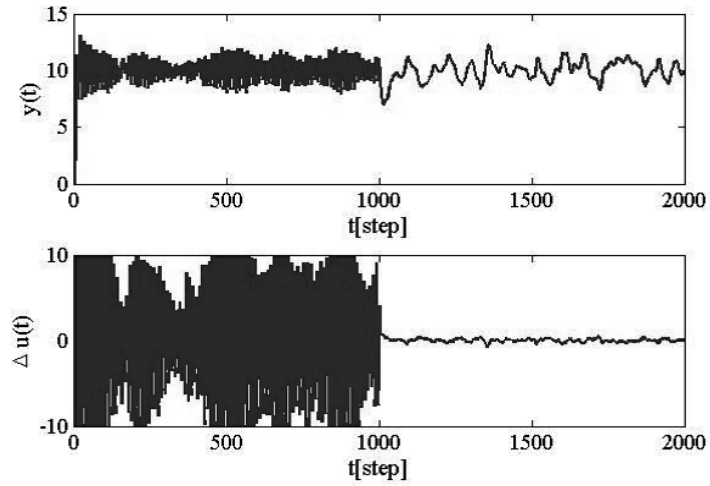

Fig. 5 Control result using the proposed control scheme in the case of $\sigma_{e}^{2}=0.8$

散が大きくなり, 逆に trade-off 関係によって, 制御入力 の分散が抑えられていることがわかる．なお，1000[step] から 2000 [step] 間の制御誤差の分散は 0.77 , 制御入力の 分散は 0.044 であり，設定した制御性能が得られている ことがわかる。なお, この場合の PID パラメータは,

$$
k_{c}=1.49, T_{I}=43.9, T_{D}=0.51
$$

であった。 
[例 2]

つぎに, システムの特性が変動する場合を想定し, 対 象とするシステムが次式で与えられるものとする。

$$
G(s)=\frac{K}{1+T s} e^{-L s}
$$

ただし，2000[step] までは例 1 と同様の特性を持ち $(T=$ 100, $K=0.9, L=15), 2001$ [step] 以降 5000[step] まで, システムゲインと時定数が以下のように変化し，むだ時 間は変化しないものとする.

$$
\left.\begin{array}{l}
T=100-\frac{50(t-2000)}{3000} \\
K=0.9+\frac{5.5(t-2000)}{3000}
\end{array}\right\}
$$

ここでも同様に，(32) 式をサンプリング時間 $T_{s}=5.0[\mathrm{~s}]$ で離散化し，モデル化誤差として平均 0 , 分散 0.001 の ガウス性白色雑音 $\xi(t)$ を付加したモデルを考える．参考 までにシステム変動後の 5000[step] 時に扔ける離散化さ れた式を以下に示す。

$$
\left(1-0.905 z^{-1}\right) y(t)=0.609 z^{-4} u(t)+\xi(t) / \Delta
$$

この制御対象に対して提案手法を適用する，ただし，最初 の 1000 [step] に扔いては, 例 1 の場合と同様, $k_{c}=8.90$, $T_{I}=30.0, T_{D}=7.50$ の $\mathrm{PID}$ パラメー夕による制御が行わ れており， $t=1000[$ step] 以降において，提案したデー夕 指向型スマート適応制御法が適用される。なお， $\sigma_{e}^{2}=0.4$ とし，算出された所望の制御入力の分散は 0.12 となっ た。その他の設計パラメータは，例 1 と同じ值にした。 このときの制御結果を Fig. 6 に，PID パラメータの調整 結果を Fig. 7 に，また $\lambda$ の調整結果を Fig. 8 に，さら に制御誤差・入力の分散の推移を Fig. 9 に示す。な扮, 1000 [step] 以降の制御誤差の分散は 0.36 , 制御入力の分 散は 0.11 であり，あらかじめ設定した制御性能を発揮し ていた。

ここでFig. 7 の $T_{I}, T_{D}$ は $1000[$ step] 以降, 3798[step] 時に一回のみ調整されているが， $k_{c}$ は $2800[\mathrm{step}]$ 付近で 複数回調整されている。 これは $8^{\circ}$ にて所望の制御性能 に対して軽微な悪化であると判断し， $\lambda$ の変更が行われ ており，(17) 式の $k_{c}$ のみがこの $\lambda$ に依存するためであ る。これらはFig. 9 からもいえる. Fig. 9 では, 制御入 力の分散が $2800[$ step] 付近で所望の分散を越えたため $\lambda$ によって所望の制御性能を維持するように調整されてお り，また 3798 [step] では，現在の制御性能が所望の制御 性能を大幅に越えたため, コントローラを再設計してい

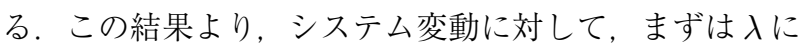
よる1-パラメータチューニングが行われ，それでも所望 の制御性能が得られない場合にコントローラを再設計し ていることがわかる。これにより効率的に PID パラメー 夕が調整される。
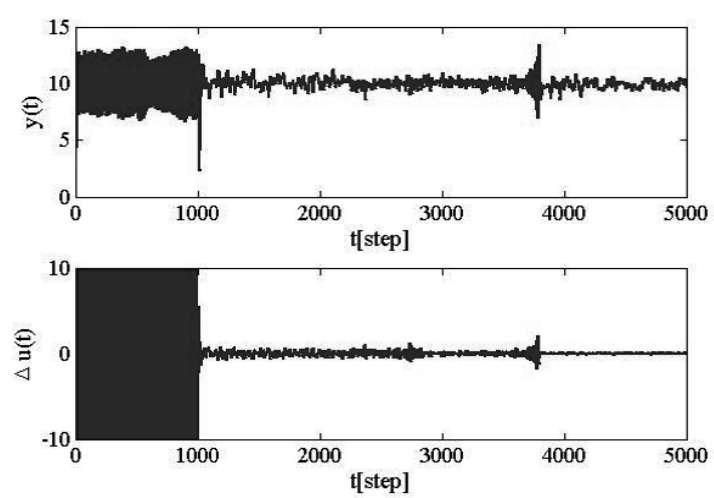

Fig. 6 Control result using the proposed control scheme in the case of $\sigma_{e}^{2}=0.4$
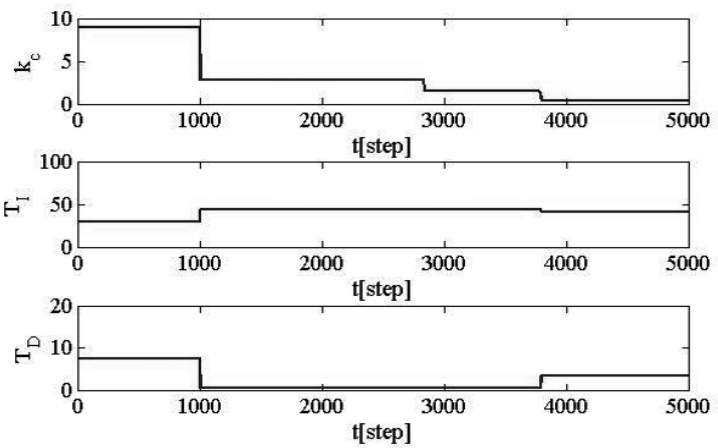

Fig. 7 Trajectories of PID parameters corresponding to Fig. 6

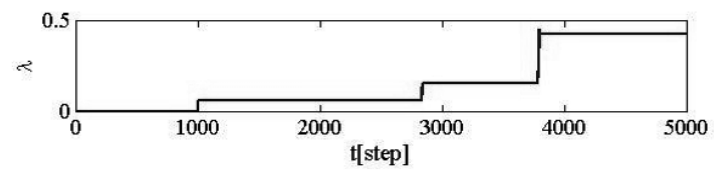

Fig. 8 Trajectories of $\lambda$ parameters corresponding to Fig. 6
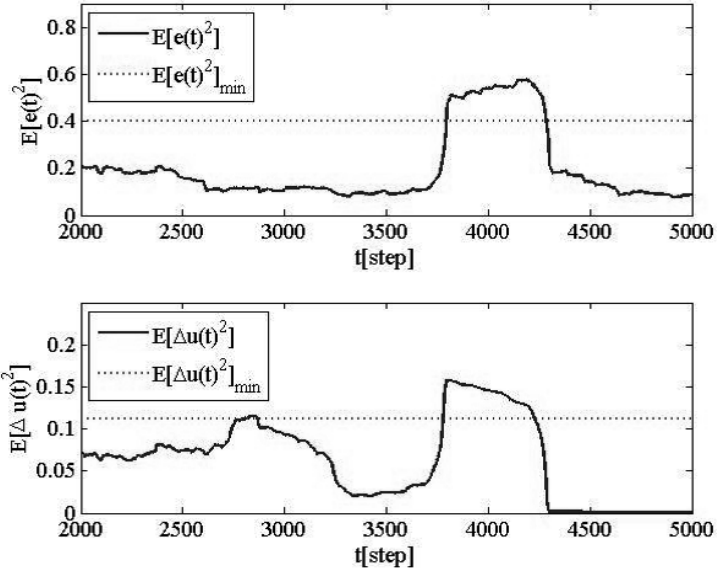

Fig. 9 Trajectories of variance corresponding to Fig. 6 ここで, $F\left(z^{-1}\right), B\left(z^{-1}\right)$ から算出されるシステムゲイ ン $K^{\prime}$ に着目する。定常状態のデー夕を用いて, $F\left(z^{-1}\right)$, 

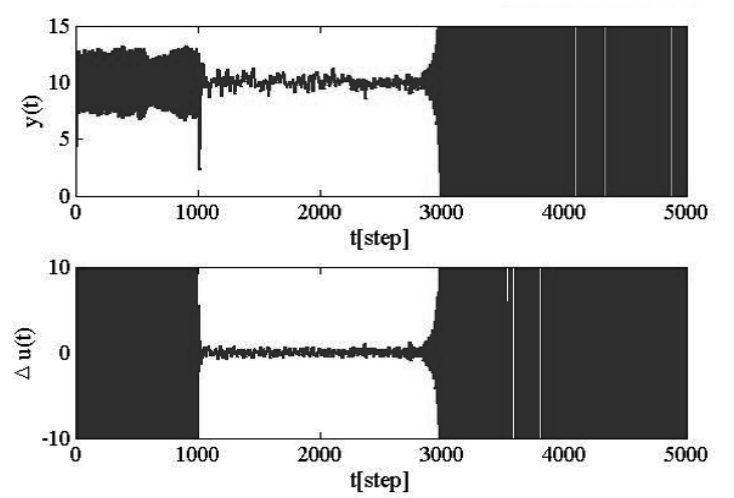

Fig. 10 Control result using the proposed control scheme where only the procedure from [step1] to [step5] is employed

$B\left(z^{-1}\right)$ を精度よく同定することは難しいが，それから 算出される定常ゲインに関しては，比較的精度よく推定 できる、いま，1000[step]では，真值となるシステムゲ イン $K$ は 0.9 であり，K'は 0.9722 となっていた。その 後, システム変動によって $3798[$ step] では $K=4.1963$ に なり，コントローラ再設計によって $K^{\prime}=4.2730$ が算出さ れた。これらのことから, システム変動が起こった場合 でもシステムゲイン $K$ の推定は精度よく行われており， それによって，コントローラ再設計後の「1-パラメータ チューニング」の効果も期待できる。 このように，本提 案手法の「1-パラメータチューニング」ならびに「コン トローラ再設計」は, システムゲイン $K$ に着目した調整 法である。

最後に，比較のために，提案した手法の $1^{\circ} \sim 5^{\circ}(\lambda に$ よる調整なし，コントローラの再設計もなし）のみを適 用した制御結果を Fig. 10 に示す。これは 1000 [step] 以 降システム変動に対して PID パラメータを調整しなかっ たことにより，最後に制御系が不安定に陥っている。こ れにより，オンラインで可調整パラメータ $\lambda$ を変更し， 必要に応じてコントローラを再設計することの有効性が 認められる。

\section{4. 結言}

本論文では，閉ループデータに基づく，制御性能を考 慮したデータ指向型スマート適応制御系の設計法につい て考察を行った，本手法の主たる特徴は，モデル構築を介 さずに，あらかじめ設定した制御性能（制御誤差の分散） を実現するように，可調整パラメータ $\lambda$ が自動調整され ることにある。また，本手法の有効性について，数值シ ミュレーションを用いて検証を行った。数值シミュレー ションでは，閉ループデータより描画された trade-off 曲 線から，ユーザが制御性能を指定することで，所望の制 御性能が得られる制御パラメータが算出されることを確 認した。また，システムが変動した場合でも可調整パラ メータ $\lambda$ を調整することによって，効率的に所望の制御
性能が得られることを確認した

今後は本手法の有効性について, サーボ系やプロセス 系の実機での検証を進める。また，本論文では制御対象 として線形系を扱ったが，今後は非線形系を対象とし， すでに著者らが提案しているデータベースを用いたデー 夕駆動型アプローチ $[22]$ と本提案手法を組み合わせた方 法についても言及する予定である.

\section{参 考文 献}

[1] K. J. Åström, U. Borisson, L. Ljung and B. Wittenmark: Theory and applications of self-tuning regulators; Automatica, Vol. 13, pp. 457-476 (1977)

[2] D. W. Clarke and P. J. Gawthrop: Self-tuning control; Proc. IEE, 126D-6, pp. 633-640 (1979)

[3] P. E. Wellstead and M. B. Zarrop: Self-Tuning Systems; Control and Signal Processing, John Wiley \& Sons (1991)

[4] 大松・山本 編: セルフチューニングコントロール, 計測 自動制御学会, 学術図書, コロナ社, pp. 17-19 (1996)

[5] 山本, 兼田: 一般化最小分散制御則に基づくセルフチュー ニング PID 制御器の一設計; システム制御情報学会論文 誌, Vol. 11, No. 1, pp. 1-9 (1998)

[6] T. Yamamoto and S. L. Shah: Design and experimental evaluation of a multivariable self-tuning PID controller; Proc. Control Theory and Applications, Vol. 151, No. 5, pp. 645-652 (2004)

[7] E. Mishkin and L. Braun: Adaptive Control Systems, McGraw-Hill (1961)

[8] I. D. Landau, 富塚: 適応システムの理論と実際, オー 么社 (1981)

[9] 金井: ロバスト適応制御入門, オーム社 (1989)

[10] K. J. Åström and B. Wittenmark: Adaptive Control, Dover Publications (2008)

[11] 岩井, 水本, 大塚 共著: 単純適応制御 SAC, 森北出版 (2008)

[12] 山本: モデリング性能評価に基づくパフォーマンス・ア ダプティブ PID 制御系の設計; 電気学会論文誌 C, Vol. 127, No. 12, pp. 2101-2108 (2007)

[13] T. Yamamoto, Y. Ohnishi and S. L. Shah: Design of a performance-adaptive proportional-integralderivative controller for stochastic systems; Institute of mechanical engineering, Part-I; Journal of Systems and Control Engineering, Vol. 222, pp. 691-699 (2008)

[14] 大西, 佐藤, 山本: 制御性能評価に基づくパフォーマン 又駆動型 PID 制御系設計; 電気学会論文誌, Vol. 132-C, No. 6, pp. 824-827 (2012)

[15] 山本: 「評価」と「設計」を統合したパフォーマンス 駆動型セルフチューニング制御系の設計 〜 1 パラメー タチューニング法〜; 計測と制御, Vol. 48, No. 8, pp. 646-651 (2009)

[16] 久下本, 吉村, 橋爪, 影山, 山本: プラント制御診断技術 の開発と適用展開; 計測自動制御学会論文集, Vol. 47, No. 9, pp. 388-395 (2011) 
[17] M. C. Campi, A. Lecchini and S. M. Savaresi: Virtual reference feedback tuning: A direct method for the design of feedback controllers; Automatica, Vol. 38, pp. 1337-1346 (2002)

[18] 金子, 吉田, 松本, 藤井: 一回の閉ループ実験データを用 いた最小二乗法に基づく制御器パラメータチューニン グ - FRIT の拡張; システム制御情報学会論文誌, Vol. 18, No. 11, pp. 400-409 (2005)

[19] 佐伯：過渡応答データに基づく PID 制御器の直接設計; 電気学会電子・情報・システム部門誌 C, Vol. 131, No. 4, pp. $722-725$ (2011)

[20] 脇谷, 細川, 山本：閉ループデータを用いたPID 制御系 の直接的設計法; 電気学会論文誌 C, Vol. 132, No. 6, pp. 873-878 (2012)

[21] J. G. Zieglar and N. B. Nichols: Optimum settings for automatic controllers; Trans. ASME, Vol. 64, No. 8, pp. 759-768 (1942)

[22] T. Yamamoto, K. Takao and T. Yamada: Design of a data-driven PID controller; IEEE Control Systems Technology, Vol. 17, No. 1, pp. 29-39 (2009)

\section{著 者略歴}

$$
\text { 架趾督总 }
$$

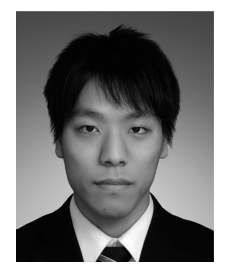

1990 年 9 月 4 日生. 2013 年 3 月広島大 学大学院工学部第二類 $($ 電気・電子・シス テム・情報系) 卒業. 同年 4 月同大学大学 院工学研究科博士課程前期 (システムサイ バネティクス専攻）に入学し現在に至る. 閉ループデータに基づく直接的制御パラ メータ算出法に関する研究に興味をもつ. 電気学会, 計測自 動制御学会の学生員.

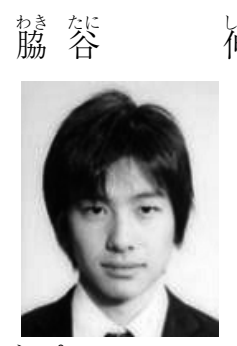

笍 (正会員)

1986 年 7 月 19 日生. 2013 年 11 月広島 大学大学院工学研究科博士課程後期 (シス テムサイバネティクス専攻) 修了．同年 12 月東京農工大学大学院工学研究院先端電気 電子部門助教となり現在に至る。閉ループ データによる直接的制御パラメータ算出法 やパフォーマンス駆動型制御に関する研究に興味をもつ。博 士 (工学). IEEE, 電気学会, 計測自動制御学会などの会員.

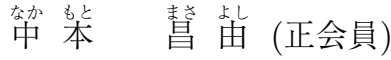

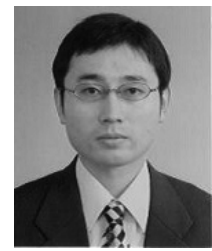

1974 年 11 月 24 日生. 2002 年 3 月広島 大学大学院工学研究科博士課程後期修了. 2002 年日本学術振興会特別研究員 PD. 現 在, 広島大学大学院工学研究院助教. ディ ジタル信号処理，制御系設計に関する研究 に従事. 博士 (工学)。電気学会, 計測自 動制御学会, 電子情報通信学会, IEEE などの会員.

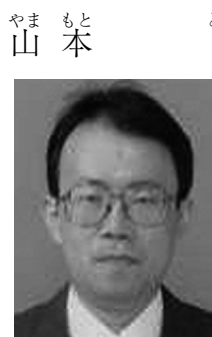

透 (正会員)

1961 年 8 月 29 日生. 1987 年 3 月徳島大 学大学院工学研究科修士課程（情報工学専 攻）修了。大阪大学基礎工学部助手, 広島 大学大学院教育学研究科技術 ·情報教育学 講座助教授，教授などを経て，2010 年同 大学大学院工学研究院電子電気システム数 理部門教授となり現在に至る。制御系設計の高度化と知能化 に関する研究に従事．工学博士．2006 年 3 9 月日本学術振 興会特定国派遣研究員（アルバータ大学化学・材料工学科）. 電気学会進歩賞, 計測自動制御学会技術賞, 日本機械学会教 育賞, 文部科学大臣表彰（科学技術賞）などを受賞. IEEE， 計測自動制御学会, 電気学会, 日本機械学会などの会員. 